\title{
THE INFLUENCE OF PARENTS' ATTITUDES IN PROVIDING EDUCATION AT HOME TOWARD THE DEVELOPMENT OF CHILDREN AGED 5-6 YEARS IN BULUSARI VILLAGE, GEMPOL SUB-DISTRICT, PASURUAN DISTRICT
}

\author{
Siti Fithrotul Umami ${ }^{1 *}$, Titiek Idayanti ${ }^{2}$ \\ ${ }^{1}$ Ar-Rahma Midwifery Academy \\ ${ }^{2}$ STIKES Dian Husada Mojokerto \\ *Correspondence: \\ Siti Fithrotul Umami \\ Email: vividfaradisa1@gmail.com
}

\begin{abstract}
Background: Development is increasing ability (skill) in the structure and function of the body that is more complex in a regular pattern and can be predicted as a result, from the results of maturation. attitude is an individual evaluation in the form of a tendency (Inclination) towards various elements outside of him. Based on the results of a preliminary study of 10 children aged 5-6 years, it was found that 5 children had normal development, 2 children doubted, and 3 children developed abnormally. While for family education conducted by parents, it was found that 7 parents supported (favorabel), and 3 parents were not supportive (unfavorable).

Objectives: The study aimed to determine the influence of parents' attitudes in providing education at home toward the development of children aged 5-6 years in Bulusari Village, Gempol Sub-District, Pasuruan District.

Methods: The research design was analytical design using purposive sampling with a sample of 45 parents and children in Bulusari Village, Gempol Sub-District, Pasuruan District. The measuring instrument used was a questionnaire for parents and KPSP for child development. This research is presented in the form of the Fisher's Exact Test.

Results: The results showed that of 38 parents $(84.45 \%)$ who supported having normal development children as many as 35 children (77.78\%). Based on the results of the Fisher's Exact Test statistical test, it was found that the value of $p<\alpha$, which is $0.001022<0.05$, which means that there is an influence from the provision of family education conducted by parents to the development of children aged 5-6 years.

Conclusion: Based on the results of this study, it is expected that efforts from health workers to increase counseling to parents so that they have a role and have an obligation to help, assist children, teach children to actively learn, give love, develop creativity and socialization of children.
\end{abstract}

Key words: Parent's attitude, development of 5-6 years, giving education in houses.

\section{INTRODUCTION}

Family is an initial institution for each individual human being to learn and interact with each other. As an institution, of course, in a family it is agreed that the rules that must be obeyed and developed by the family, which are meant here, are nuclear families consisting of Father, Mother and child. As all of Eastern culture that embraces the principle of patriarchal, that the captain (head) in a nuclear family is a father. Because it is, he who is responsible 
for providing for all family members and is also responsible for the survival of the family as a whole, including educating children. In carrying out his role as head of the family, especially as a child educator, a father will work with his wife, in this case the mother of her children. Furthermore, the father and mother are called parents who have full responsibility for the development of their children.

With the increase in the size of the child, it requires education, attention and greater understanding from parents (Soetjiningsih, 1995). The influence of the period of maturity and sensitivity of children, educators (parents) should see to it that at the time of maturity there are no obstacles that hinder the development of these functions. Because obstruction of psychic function at sensitive times can lead to setbacks in individual children (Kartini, 1995).

The relationship between children and family is generally important, but the attitude of parents is the most important element in shaping the developing selfconcept. Soft and hard methods of education will affect children (Hurlock, 1980). Very young children feel anxious. Especially feeling anxious about losing your love, attention, and support from your parents. To overcome feelings of fear in children, the attitude of parents who are calm and wise is needed. Fear and anxiety also often arise, if parents are too fussy and very demanding of children. Demands that are not real and not in accordance with the abilities of children, will lead to chronic fear of doing something and achieving (Kartini, 1995).

The task of the teacher is to help parents guide and develop children's potential to be more focused. Once again, the nature only helps, no matter how much effort a teacher does without the help of parents the results are futile. Because the teacher's time with children and parents with children is $25 \%$ and $75 \%$. More or less children only have $25 \%$ a day with the teacher in the school, the remaining $75 \%$ of children spend time with parents at home. After all, when a child is in school, a teacher will not be able to pay attention to their students one by one which sometimes exceeds the capacity, and in this problem the teacher has no authority, the teacher only carries out the task of teaching and becoming an educator. Even though the child has been handed over to the school, it does not mean that the child's education affairs are the responsibility of the school and parents are free and neglect the child's education. In this case the parents must do is establish good cooperation and communication with the school or the teacher, so that there is no misunderstanding in educating children.

Many factors that influence the level of child development include stimulation, upbringing and stimulation, and nutrition that is given in infancy. The more stimulation that is given, the more complex the neural network is formed. Forms of poor parenting will result in stubborn children. Lack of stimulation and delay provide stimulation by parents, causing potential and certain abilities not to materialize. Parents must be vigilant if a child has a developmental delay, if found delay or storage should be examined or determine whether it is a normal variation or a serious abnormality. Because the child's sensitivity to the environment does not last long, the child must get serious attention early in life, namely good nutrition, adequate stimulation, eliminating factors that can disrupt children's development, as well as early detection of developmental irregularities.

Family education as the foundation for forming a child's personality. Since childhood, children live to grow and develop in families. The entire family that first filled the child's personality. Parents with unplanned instill habits inherited from the family. Thus Cyanak will bring wherever the influence of the family, even though he has begun to think further. The 
bigger the child, the more widespread the influence will be until finally the entire environment, whether it be coastal areas, mountains, valleys, or forests, affects the whole life of the child (Sujanto, et al., 2004).

Based on the results of a preliminary study conducted by researchers on 25 June 2016 in Bulusari Village, Gempol SubDistrict, Pasuruan District, 10 children aged 5-6 years, it was found that 5 children had normal development, 2 children doubted, and 3 children developed abnormally. While for family education conducted by parents, it was found that 7 parents supported (favorabel), and 3 parents were not supportive (unfavorable).

From the background of the problem above the researcher was interested in conducting research about "The influence of parents' attitudes in providing education at home toward the development of children aged 5-6 years in Bulusari Village, Gempol Sub-District, Pasuruan District".

\section{METHODS}

Study Design

The type of research conducted in this study was analytical research.

\section{Setting}

The study was conducted in Bulusari Village, Gempol Sub-District, Pasuruan District.

\section{Research Subject}

The research population was parents and children in Bulusari Village, Gempol Sub-District, Pasuruan District. The sample in this study was 45 respondents with the sampling method using purposive sampling.

\section{Instruments}

The measuring instrument used is a questionnaire for parents and a KPSP (Pre Development Screening Questionnaire) tool, which is a tool for estimating child development, which includes the development of children's social, motoric, and language from 1 month to 6 years, where the tool is a method screening for child development abnormalities, but also this test is not an IQ test or a diagnostic test. The questionnaire used to determine parental attitudes in providing home education consisted of 20 closed question, of which 20 questions contained 3 components, namely 7 questions with affective components, 7 questions with cognitive components, and 6 questions with psychomotor components.

\section{Data Analysis}

This study is presented in the form of Fisher's Exact Test statistical test with a value of $\alpha \leq 0.05$.

\section{Ethical Consideration}

This research has obtained permission from National Unity and Politics of Pasuruan Regency.

\section{RESULTS}

Characteristics of Respondents by Parent's Attitude in Providing Education at Home

Table 1. Distribution of Frequency of Respondents by Parent's Attitude in Providing Education at Home in Bulusari Village, Gempol Sub-District, Pasuruan District $(\mathrm{n}=45)$.

\begin{tabular}{lcc}
\hline Parent's Attitude & Frequency & Percentage (\%) \\
\hline $\begin{array}{l}\text { Favorabel } \\
\text { (Supportive) }\end{array}$ & 38 & 84.45 \\
$\begin{array}{l}\text { Unfavorabel (Not } \\
\text { Supportive) }\end{array}$ & 7 & 15.55 \\
\hline Total & 45 & 100.00 \\
\hline Sources: Primary Data of Questionnaire
\end{tabular}

Based on table 1 above, it was found that the attitude characteristics of parents in providing education at home were almost entirely favorable (supportive) as many as 38 parents $(84.45 \%)$ and the remaining 7 parents $(15.55 \%)$ were unfavorable (not supportive). 
Characteristics of Respondents by Development of Children Aged 5-6 Years

Based on table 2, it was found that the development of children was mostly / almost entirely normal, as many as 37 children $(82.22 \%)$; doubting as many as 8 children (17.78\%); and there are no abnormal children.

Table 2. Distribution of Frequency of Respondents by Development of Children Aged 5-6 Years in Bulusari Village, Gempol Sub-District, Pasuruan District (n $=45$ ).

\begin{tabular}{lcc}
\hline $\begin{array}{l}\text { Development of } \\
\text { Children Aged }\end{array}$ & Frequency & $\begin{array}{c}\text { Presentase } \\
\text { 5-6 Years }\end{array}$ \\
\hline Normal & 37 & 82.22 \\
Doubted & 8 & 17.78 \\
Abnormal & 0 & 0.00 \\
\hline Total & 45 & 100.00 \\
\hline
\end{tabular}

Sources: Primary Data of Questionnaire

Cross distribution of the influence of parents 'attitudes in providing education at home with the development of children aged 5-6 years in Bulusari Village, Gempol District, Pasuruan Regency, August 2016. Effects of parents' attitudes in providing education at home with the development of children aged 5-6 years. Of 38 parents $(84.45 \%)$ who supported having normal development children as many as 35 children (77.78\%), and doubted as many as 3 children $(6.67 \%)$. Whereas from 7 parents $(15.5 \%)$ who did not support having normal development children as many as 2 children $(4.44 \%)$ and 5 children $(11.11 \%)$ whose development was doubtful. Based on the results of the Fisher's Exact Test statistical test, it was found that the value of $p<\alpha$, which is $0.001022<0.05$, which means that there is an influence from the provision of family education conducted by parents to the development of children aged 5-6 years.

\section{DISCUSSION}

From the results of the study it can be seen that $38(84.4 \%)$ of 45 respondents were said to be favorable (supportive), where the attitude of parents was almost entirely supportive in providing education at home. And 7 respondents (15.5\%) from 45 respondents were unfavorable (not supportive).

Based on the research data, it was found that the majority were from 5.1 to 6 years old, $28(62.22 \%)$ of children from 45 respondents and some of them were 5 years old, $17(37.78 \%)$ of 45 respondents. When viewed in terms of age, at this age level children already have the knowledge and insight to socialize with friends and other environments, so that children already have courage. From this knowledge creativity will be formed, in this study it can be seen that the results of KPSP examination, obtained mostly are normal with 37 $(82.22 \%)$ children of 45 students in Bulusari Village, Gempol Sub-District, Pasuruan District. Various detection methods to determine the child's developmental disorders have been made, as well as screening to find out potential diseases that can lead to developmental disorders, because early detection of abnormalities is very useful, so that the diagnosis and recovery can be done earlier (Nelson, 2000).

Based on the data obtained from the results of the study, it was found that almost all attitudes of parents who provided home education with child development showed support or favorabel $(84.45 \%)$ with 38 parents of 45 parents studied and the development of children aged 5-6 years. also almost entirely said to be normal $(82.22 \%)$ with the number of children 37 out of 45 children studied. The data analysis used is the Fisher Exact Test method between the attitudes of parents who provide education at home with the development of children aged 5-6 years obtained $\mathrm{p}<\alpha$, which is $0.001022<0.05$ so that $\mathrm{H} 0$ is rejected and $\mathrm{H} 1$ is accepted. And the conclusion is that there is influence with 
the attitude of parents in providing education at home with the development of children aged 5-6 years in Bulusari Village, Gempol Sub-District, Pasuruan District.

Basically, parents are the main factors that influence children's habits, so the role of parents is very important for the formation and development of children. Then the results of the processed data on "The influence of parental attitudes in educating children at home with the development of children aged 5-6 years" in accordance with the concept which explains that the statement of attitude contains positive things about the object attitude, namely the sentence is supportive or impartial to the object attitude (Azwar, 2003). The attitude of parents will influence the way they treat children, besides that it also affects the attitudes and behavior of children, basically children depend on the attitude of parents (Hurlock, 2005). Positive or supportive attitudes of parents to children will be far better than if parents' attitudes are not positive. Positive attitudes here can be shown at the expense of their personal interests and activities to devote time and attention to children, for example guiding and supervising children to routinely learn and provide opportunities for children to create according to their age. Conversely, negative attitude criteria occur when parents who are less able / unable to give attention and affection to children, parents are not able to provide positive support to children so that children tend to be egocentric. So with the maximum role of parents it is expected to be able to support the development level of the age of 5-6 years, this is based on that in the family of parents is very important role in educating and supervising children in addition to school. The active role of parents in question is: direct effort towards children and the first experienced by children, nurturing and fostering children, educating children is an obligation for every parent in an effort to shape the child's personality.
By protecting and protecting and instilling compassion for their children so that these children will be provided with compassion for others. At the ages of the preschool (5-6 years) this guidance and demand is better done by giving good examples. So it is clear the role of parents in the development of children aged 5-6 years is supported by the results of the 2016 study conducted by researchers.

\section{CONCLUSION}

The attitude of parents in providing education at home is almost entirely supportive (favorabel) with the development of children aged 4-6 years with a percentage of $84.4 \%$, namely 38 respondents from 45 respondents. Children aged 5-6 years in Bulusari Village, Gempol Sub-District, Pasuruan District after being tested for child development using KPSP found that almost all child development in the normal category amounted to 37 $(82.22 \%)$ children from 45 respondents. There is an influence of parents' attitudes in providing education at home to the development of children aged 5-6 years. It can be said that there is a real influence between the two variables, with a value of $\mathrm{p}<\alpha$, which is $0.001022<0.05$.

\section{SUGGESTIONS}

Based on the results of the study, it is expected that this research can be an input and reference for further researchers in developing and perfecting research by improving the limitations possessed by researchers. In addition, the results of this study can be a forum for the development of science and can reproduce references to literature, especially the attitudes of parents in providing home education and child development. For parents, it is expected to pay more attention to children's activities during the child outside school hours, in this case is as long as the child is at home. Parents also play a role and have an obligation to help, accompany children, teach children to actively learn, give 
affection, develop creativity and socialization of children, it will form a personality that is as good as possible in children so parents can control the development of children.

\section{REFERENCES}

Alimul, A. A. (2007). Pengantar Ilmu Keperawatan Anak I. Jakarta: Salemba Medika.

Arikunto, S. (2010). Prosedur Penelitian Suatu Pendekatan Praktik. Jakarta: PT Rineka Cipta.

Azwar, S. (2007). Sikap Manusia. Edisi ke2 Cetakan X. Yogyakarta: Pustaka Pelajar.

Hurlock, E. B. (1980). Psikologi Perkembangan. Edisi ke-5. Jakarta: Erlangga.

Hurlock, E. B. (2005a). Perkembangan Anak. Jilid 2. Jakarta: Erlangga.

Psikologi Perkembangan. Edisi ke-5. Jakarta: Erlangga.

Kartono, K. (2007). Psikologi Anak/Psikologi Perkembangan. Cetakan V. Penerbit: Mandar Maju.

Notoatmodjo, S. (2002). Metodologi Penelitian Kesehatan. Jakarta: PT Rineka Cipta.

Notoatmodjo, S. (2003a). Ilmu Kesehatan Masyarakat. Jakarta: PT Rineka Cipta.

Notoatmodjo, S. (2010). Metodologi Penelitian Kesehatan. Jakarta: PT Rineka Cipta.

Nursalam. (2008). Konsep dan Penerapan Metodologi Ilmu Keperawatan. Jakarta: Salemba Medika.

Soetjiningsih. (1998). Tumbuh Kembang Anak. Jakarta: EGC.

Cite This Article As: Umami, S.F., \& Idayanti, T. The Influence of Parents' Attitudes in Providing Education at Home Toward the Development of Children Aged 5-6 Years in Bulusari Village, Gempol Sub-District, Pasuruan District. Nurse and Health: Jurnal Keperawatan 2019; 8(1): 56-61. 